\title{
From Accountability to Readability in the Public Sector: Evidence from Italian Universities
}

\author{
Alessandra Allini ${ }^{1}$, Luca Ferri ${ }^{1}$, Marco Maffei ${ }^{1} \&$ Annamaria Zampella ${ }^{1}$ \\ ${ }^{1}$ Department of Economics, Management, Institutions, University of Naples Federico II, Italy \\ Correspondence: Alessandra Allini, Department of Economics, Management, Institutions, University of Naples \\ Federico II, Italy. E-mail: luca.ferri@unina.it
}

Received: January 20, 2017

Accepted: February 1, 2017 Online Published: February 22, 2017

doi:10.5539/ijbm.v12n3p27

URL: https://doi.org/10.5539/ijbm.v12n3p27

\begin{abstract}
This paper aims to explore the readability of the disclosure provided by Italian universities that changed their accounting systems to accrual accounting over the past three years. The transition from cash to accrual accounting not only concerns financial statements, but also the related notes. Indeed, the Italian government has paid great attention to the narrative sections of reports due to their capacity to provide more transparency. To provide better accountability, financial statements must be readable for all stakeholders. We used two different indexes, namely the Gunning fog and GULPEase indexes. The analysis was conducted on a sample of universities to analyze the narrative sections of the first financial statements prepared according to the new accounting system in 2012-2014. The final sample comprised 32 Italian universities. The research results demonstrated low readability in the balance sheets of Italian universities after switching to accrual accounting, illustrating an unsatisfactory level of accountability.
\end{abstract}

Keywords: University, accountability, accrual accounting, readability

\section{Introduction}

In recent years, mainly in the wake of new public management (NPM), several reforms have hardly affected the higher education setting (Olson et al., 1998). Thus, universities have been subject to institutional pressures that have led to the adoption of new accounting practices (e.g., Lapsley \& Miller, 2004; Bogt \& Scapens, 2012). In particular, the introduction of the accrual accounting fits with the NPM, which emphasizes efficiency and effectiveness, through the use of quantitative performance measures (Scapens, 1985; Hood 1995; Olson et al. 1998). It has been argued that accrual accounting provides more complete and accurate information that leads to broader transparency (Cinquini, 2002; Ricci, 2013; Paolini \& Soverchia, 2013 and 2014). Indeed, together with performance, transparency is another essential feature of NPM (Bogt \& Scapens, 2012), and disclosure is conceived as a tool that may ensure accountability, since it is supposed to foster clarity (Steccolini, 2004; Bovens, 2010; Almquist et al., 2013). Therefore, the improvement of accountability is at stake, and its ability to meet stakeholders' information needs and achieve transparency depends on the characteristics of disclosure in complying with several requirements. Among them, readability is of great importance: Information that is not comprehensible maybe not useful, and therefore, it will make a lesser contribution to ensuring adequate accountability (Wallace et al. 1994).

This issue has substantial relevance in Italy, where a pervasive regulatory transformation is taking place among public universities with the aim of making their governance and accounting systems accountable to stakeholders (Steccolini 2004; Riccaboni \& Galgani 2010; D’Alessio, 2012; Ricci, 2013; Caldarelli et al. 2014). The more incisive change can be traced back to Law No. 240/2010 and Law No. 18/2012, which mark the transition from cash to accrual accounting systems. This reform - mandatory from 2015, but optional since 2012 - is still in progress, and currently, the debate is principally centered on the adequacy of the new financial reporting in pursuit of accountability (Lapsley et al. 2009; Mussari \& Sostero, 2014).

To date, despite their importance, there has been scarce research on disclosure practices in universities. The Italian setting offers a window of opportunity to explore whether the new financial reporting system can foster accountability. More specifically, this study aims to test the degree of readability of the "first" financial reporting prepared by Italian universities according to the new rules. 
The issue of readability has been widely discussed in literature concerning the private sector (e.g., Dale \& Chall, 1949; Smith \& Smith, 1971; Barnett \& Leoffer, 1979; Smith \& Taffler, 1992; Shrand \& Walter, 2000; Bloomfield, 2002; Courtis, 1995; Li, 2008). However, to the best of our knowledge, no empirical research has been carried out in the public sector. To achieve this aim, we used the two most common indicators - the Gunning fog index (Gunning, 1978) and the GULPEase index (Lucisano \& Piemontese, 1988) - to measure the readability level of information conveyed in the notes of financial statements for a sample of 36 public Italian universities that decided to adopt the accrual accounting system in advance, during the period of 2012-2014.

Overall, the study highlights just enough readability of notes to financial statements after the first transition and suggests that the government should introduce new, different mechanisms to ensure and improve the readability of the narrative section of the balance sheet. In fact, the average value of both indexes is around 0.6 (the readability is considered good for value greater than 0.7 ). Moreover, this work highlights the existence of a lack of influence of size and geographical variables on the readability of the disclosure.

This paper's contribution is twofold. First, it enriches the academic debate on the critical issues related to the benefits underlying changes in the accounting system in universities. Second, our findings can help regulators to develop appropriate rules and regulations that may ensure disclosure of comprehensive financial information able to meet stakeholders' information needs and foster accountability.

The paper is organized as follows: Section 2 provides a theoretical framework of the new university accounting system and a brief review of the literature on readability. Section 3 describes the method used, while Section 4 describes the research results. Finally, Section 5 provides a discussion and conclusions.

\section{From Accountability to Readability in Italy}

With the introduction of Law 240/2010, universities were forced to switch from financial accounting to accrual accounting (Mussari \& Sostero 2014). Accrual logic focuses on the economic result of the period and the related working capital (Catturi et al. 2004; Anessi Pessina \& Steccolini 2007; Anselmi et al. 2012). Many authors have stated that the main principles behind the Italian universities' reform involved the need to ensure coherence between planning and reporting, increase transparency, ensure consistency of accounting items, and monitor the behavior of government bodies (Ricci, 2013; Paolini \& Soverchia, 2014). According to many scholars, accrual accounting allows organizations to better pursue their goals, and it fits with the NPM (Hood 1995; Olson et al. 1998). Several studies have highlighted the main advantages of accrual accounting in the assessment of organizations' economic results and the financial position, the long-term assessment of strategies, and the improvement of data-entry procedures to guide and support the decision-making process (Guthrie and Parker, 1990; Perrin, 1998; Paolini \& Soverchia, 2014).

The recent reform was introduced by the Italian government to increase the degree of accountability, with a particular focus on the need to satisfy the expectations about the real capacity of universities to produce and distribute value (Caperchione \& Mussari 2000; Borgonovi 2002; Monfardini 2010; Anselmi et al. 2012; Mussari, 2012; Mussari \& Sostero 2014).

The scientific debate about the meaning of accountability within the public sector is still ongoing It has recently been interpreted more broadly based on a double perspective, namely as a virtuous behavior that provides legitimacy to public Organizations and as a mechanism used to achieving accountable governance (Bovens, 2010). Due to universities' social mission, they should have accountable financial statements to allow stakeholders to have useful, accurate information. On this basis, it is worth noting that the law 19/2014 clarifies that a university's financial statements must be useful for a great number of stakeholders.

Financial reporting is useful to stakeholders when it encompasses comprehensibility (clarity). However, comprehensibility cannot be reduced to a simple "morphological appearance" (which relates to the formal establishment of the Notes to financial statements; Pica, 1994). Instead, it must be checked in terms of the syntactical (concerning the financial statement's logic and expressivity) and lexical (to avoid terminological ambiguity) dimensions. In fact, disclosure should not be just useful and understandable; it must also ensure a good level of accountability (Lebar, 1982; Loughran \& McDonald, 2014).

Many authors have proposed different models to measure readability as an indicator of the degree of comprehensibility (McLaughlin \& Harry, 1969; Klare, 1974; Franchina \& Vacca, 1986) or explain the relevant differences in readability in different sectors (Healy, 1977; Patton, 1992; Haniffa \& Cooke, 2002). What should be noted is that the meaning of readability is not absolute, and its measurement appears to be strongly influenced by the definition authors employ. For instance, based on the textual style and consistency of lexical text, Klare (1974) describes readability as "the ease of understanding or comprehension due to the style of writing." 
Empirically, many studies have focused on readability in the private sector. Some authors have assessed the main factors that provide higher or lower readability (Schrand \& Walther, 2000; Bloomfield, 2002; Li, 2008), others have investigated its main effects (Lehavy et al. 2011; Bozanic \& Thevenot 2014), and still others have analyzed this level based on ad hoc information during special events (Flory et.al 1992; Courtis, 1995; Lehavy et al. 2011; Loughran \& McDonald, 2014).

Chavkin (1997) examined the level of complexity of corporate texts (financial statements and other documents) with reference to two critical features, as follows: the difficulty of the words (a difficult word is a "technical" word) and the length of sentences. The author highlights that simple sentences with easier words (words with fewer than four syllables) provide better intelligibility. More recently, other scholars have shown that the readability of financial statements may be affected by the company's performance (Li, 2008; Biddle et al., 2009). Indeed, they have discussed the influence of the economic and financial results in the Notes on financial statements' readability. According to these authors, management usually tries to hide firms' negative results behind unreadable disclosure (or conversely, they try to enhance the positive results with more understandable disclosure). This is known as the "management obfuscation hypothesis," and it has been verified by numerous authors (e.g., Li, 2008; Biddle et al., 2009).

The studies described above have all focused on listed companies belonging to the private sector; thus, they have neglected the importance of the issue of readability in the public sector, where accountability is a fundamental paradigm. The lack of previous research is especially noticeable in the context of the university given the recent reform process. Addressing this lack of research, the present study represents the first investigation of the degree of readability of universities' financial statements, ultimately discussing the adequacy of accounting language in fulfilling accountability.

\section{Research Design}

\subsection{Sample}

The analysis was conducted on a sample of Italian universities, where the decision was made to adopt accrual accounting in the first years. Italy represents an interesting setting to explore, since the introduction of Law 240/2010 forced universities to switch from financial accounting to accrual accounting (Mussari \& Sostero 2014). Accrual logic focuses on the economic result of the period and the related working capital (Catturi et al. 2004; Anessi Pessina \& Steccolini 2007; Anselmi et al. 2012). Many authors have stated that the main principles behind the Italian universities' reform are ensuring coherence between planning and reporting, increasing transparency, ensuring consistency of accounting items, and monitoring the behavior of government bodies (Paolini \& Soverchia, 2014). The Italian government introduced the recent reform to increase the degree of accountability, with a particular focus on the need to satisfy the expectations concerning the real capacity of a university to produce and distribute value (Caperchione \& Mussari 2000; Borgonovi 2002; Monfardini 2010; Anselmi et al. 2012; Mussari \& Sostero 2014).

Our analysis involved a sample of Italian universities that engaged in early adoption of accrual accounting. From the original population, we eliminated private universities and those that had not opted for the early transition from cash accounting to accrual accounting before 2015. In addition, five other universities were excluded because, as of the date of analysis, they had not published financial statements. Thus, the final sample consisted of 36 public universities. For every university of the sample, we examined the first financial statement after the declaration of the transition from cash accounting to accrual accounting, which occurred in the interval of 2012-2014. It should be noted that in four cases, it was not possible to find the financial statements. Despite the comments and the declarations regarding the formal switch to accrual accounting (found online), these universities did not publish their financial statement online. Therefore, the final sample comprised 32 universities. Table 1 shows the composition of the sample in relation to the year of transition.

Table 1. Universities that Switched to Accrual Accounting

\begin{tabular}{lll}
\hline Year of transition & N. of universities & \% of total sample \\
\hline 2012 & 7 & $21.9 \%$ \\
2013 & 17 & $53.1 \%$ \\
2014 & 8 & $25.0 \%$ \\
Total & $\mathbf{3 2}$ & $\mathbf{1 0 0 \%}$ \\
\hline
\end{tabular}




\subsection{Research Method}

To measure the degree of readability, we proposed two different indicators, namely the Gunning fog index (Gunning, 1952) and the GULPEase index (Lucisano \& Piemontese, 1988). We chose to develop a double-index measurement to validate the results obtained (Franchina \& Vacca, 1986). Furthermore, we choose these two indicators because they are the most frequently used in the literature, and they provide considerable advantages compared to other existing indexes.

The Gunning fog index (1980) is based on the following algorithm:

$$
R=0.4 \times[(n . \text { Words } / n \text {. Sentences })+100 \times \text { (n. Complex words } / n . \text { Words })]
$$

where:

\section{$R=$ degree of readability.}

This approximately reflects the minimum number of years of education that a common person requires to easily read and understand a text. Usually, a Gunning fog index below 12 indicates better text readability. This index can be easily adapted to the Italian language.

The other indicator used in this research was the GULPEase index (Lucisano \& Piemontese, 1988). This is obtained using the following algorithm:

$$
R=89+[300 x \text { (number of sentences) }-10 x \text { (number of letters) }] / \text { (number of words) }
$$

This indicator provides normalized values that range between 0 and 100 . The upper edge of " 100 " indicates a high degree of readability, while " 0 " represents a low readability. Researchers have attempted to identify three value ranges to facilitate the interpretation: Narrative texts with an index lower than 80 are difficult to read for all people who have only completed primary school. A readability index lower than 60 indices means that the text is difficult to read for those who have completed middle school. Finally, a readability index lower than 40 indicates a difficult text to read for those with a high school diploma (Lucisano \& Piemontese, 1988). This index presents a double advantage. First, it was developed for the Italian language, so it does not require any adaptation. Moreover, Lucisano \& Piemontese (1988) take into account the number of letters and not the number of syllables (as Gunning did) to avoid the risk of a distortion of the analysis caused by "long" words (Seah \& Tarca, 2006). In light of these considerations, the GULPEase index appears to be the most appropriate for the aim of this paper, while the Gunning fog index the best comparison tool to confirm our findings.

Following the approach used in previous studies, the data collection was manual (Weber, 1985; Beattie et al., 2004; Seah \& Tarca, 2006). More specifically, for each financial statement, we considered the all text within the notes. Indeed, the Italian government recommended that for all universities that choose to change the accounting rules, the preparation of a reconciliation statement and an ad hoc explicative paragraph that allows users to understand all critical issues related to migration to the new accounting regime.

\section{Results}

It should be noted that just a few universities were fully transparent. Table 2 provides brief descriptive details.

Table 2. Universities' information

\begin{tabular}{lllll}
\hline Year of transition & N. of Universities & \%of the sample & $\begin{array}{l}\text { N. of universities with a Existence of ad hoc paragraph on the } \\
\text { reconciliation statements } \\
\text { transition }\end{array}$ \\
\hline 2012 & 7 & $21.9 \%$ & 1 & 2 \\
2013 & 17 & $53.1 \%$ & 3 & 14 \\
2014 & 8 & $25 \%$ & 1 & 13 \\
Total & $\mathbf{3 2}$ & $\mathbf{1 0 0 \%}$ & $\mathbf{5}$ & $\mathbf{2 9}$ \\
\hline
\end{tabular}

Table 2 shows that just $15.6 \%$ of the sample introduced a reconciliation statement to improve and facilitate the external reader's understanding of the criteria used in the switching process. In addition, $80 \%$ of the sample ( 29 out 32) reserved a narrative section illustrating the critical issues of the transition.

This section provides the research results. For each university, a dual measurement of readability was reported based on the GULPEase and Gunning fog indexes to detect the existence of significant differences between the mean values of the indices in the various years (see Table 3 ). 
Table 3. Readability results

\begin{tabular}{llllll}
\hline Year of transition & N. of Universities & Average value of words & $\begin{array}{l}\text { Average number of } \\
\text { sentences }\end{array}$ & $\begin{array}{l}\text { Average value of } \\
\text { Gunning fog index }\end{array}$ & $\begin{array}{l}\text { Average value of } \\
\text { Gulpease index }\end{array}$ \\
\hline 2012 & 7 & 3.359 & 229.70 & 22.64 & 62.71 \\
2013 & 17 & 6.534 & 704.58 & 22.55 & 64.02 \\
2014 & 5 & 5.459 & 530.13 & 20.82 & 65.48 \\
\hline
\end{tabular}

For the year 2012, just seven universities decided to switch to the accrual accounting system. As Table 2 shows, the average value of words used in the preparation of the notes amounted to 3.359 , with an average number of sentences amounting to 229.7. Both indices reflect a poor readability situation. Indeed, the GULPEase index stood at 62.71, highlighting a possible difficulty for the reader in the text understanding (a value of 60 is judged just enough). These results were confirmed by the Gunning fog index, which highlighted the poor readability of the universities' notes to financial statements (the average value was 22.64).

In 2013, 17 universities chose to switch to accrual accounting. Compared to the previous subsample, in this case, the average number of words used to describe the transition was lower (6.534), while the number of sentences is 704.58. The results for this subsample show the use of a smaller number of words per sentence, suggesting that the accountants placed greater emphasis on the readability of the document by providing shorter, less complex sentences. In terms of readability, this view was supported by the average value of GULPEase, which increased by about 1.3 points (64.02) compared to the previous year. Nonetheless, the Gunning fog index results were almost the same (the improvement is barely noticeable). This change can probably be attributed to a higher incidence of "difficult words." Thus, while there was a sufficient degree of readability of the notes due to the shorter sentences, the sentences were composed of slightly more difficult words. What should be noted is that the differences between the two indicators are not significant and they show a modest gap for 2012 and 2013.

Finally, for 2014, the remaining eight universities that decided to switch to the new accounting rules were analyzed. This subsample showed a higher value of readability compared to the 2013 sample. Indeed, the average number of words was 5.459, while the average number of sentences was 530.13. Consequently, the GULPEase index revealed an increase of 1.5 points over 2013, and this means a discrete degree of legibility, while the Gunning fog index was lower by about 2 points, representing a decreased reliance on more technical ("difficult") words in the 2014 subsample. The reductions in the average number of words per sentence and the use of difficult words generated a significant improvement in the value of both indices, thereby confirming an overall improvement in the readability of the notes of the universities investigated. What should be noted is that there was a significant improvement in the readability of the notes to financial statements compared to previous years (2012) when the first universities moved to accrual accounting.

To improve the quality of this research, we repeated the measure of readability by classifying the sample first by size (small, medium, and large universities). The reclassification was carried out using the sum of the number of teachers and researchers for each university, in line with the research of Paolini et al. (2016). Thus, we considered small universities as those with under 500 staff members, medium universities as those with 500-1000 staff members, and finally, large universities as those with more than 1000 staff members. We expected results similar to those discovered in firms by other authors (i.e., Li et al. 2009). More specifically, we expected that the larger universities would provide better readability than smaller ones due to their higher visibility which are subjected. Table 4 summarizes the results of the examination, showing an almost equal division of universities in the two groups.

Table 4. Differences Between Small, Medium, and Large Universities

\begin{tabular}{llllll}
\hline $\begin{array}{l}\text { University } \\
\text { dimension }\end{array}$ & $\begin{array}{l}\text { N. of } \\
\text { universities }\end{array}$ & & $\begin{array}{c}\text { Average value of words } \\
\text { Average number of sentences }\end{array}$ & $\begin{array}{l}\text { Average value of Gunning fog index } \\
\text { Average } \\
\text { value of } \\
\text { Gulpease } \\
\text { Index }\end{array}$ \\
\hline Small & 10 & 5397.9 & 568 & 21.18 & 22.04 \\
Medium & 15 & 5240 & 425.6 & 23.71 \\
Big & 7 & 4569 & 530.78 & & 61.64 \\
\hline
\end{tabular}


Table 4 shows different results from our expectations. In fact, what should be noted is that there are no particularly significant differences in GULPEase indexes between large and small universities. The difference between the indices is about 0.2 . The only significant difference between the two groups is exhibited by the Gunning fog index, which shows a greater difficulty in the readability of the notes to financial statements of large universities than small ones. This difficulty can be attributed to the increased presence of difficult words that are frequently used in the disclosure of the bigger universities. More specifically, the small universities provide an informative average longer than the others do, with a large number of phrases and words per sentence, thereby making the text more complex. Therefore, the attempt to provide a more readable disclosure through a longer (and probably less technical) explanations results in worse readability of the notes to financial statements. Another possible explanation is that in small universities, the management of the switching process incorporates a moderate level of complexity thanks to the leaner structure, while at the same time, the amount of accounting inputs to manage is less complex.

In Table 4, what should be noted that there is a considerable difference in readability (about 5 points) between the medium-sized universities and the other categories. This difference depends on the use of an acceptable number of words per phrase and the moderate introduction of difficult words.

\section{Concluding Remarks}

The aim of this study was to examine the readability of Italian universities' balance sheets, after the transition to accrual accounting. The research was conducted using two different measures of readability, namely the Gunning fog and the GULPEase index. Previous research had not been conducted on the readability of universities' balance sheets, but this topic has recently assumed greater significance due to the importance of accountability principles in the public sector. In addition, greater emphasis has been placed on the content of information conveyed in the new position papers. Indeed, the Italian government proposed a complex process of change inspired by accountability principles, and more specifically, the need to provide more transparency and efficiency in universities (Steccolini 2004; Riccaboni \& Galgani 2010; Caldarelli et al. 2014; Paolini \& Soverchia, 2014). What should be noted is that the degree of transparency doesn't only depends on the accuracy of the data provided in the balance sheet, but also the accompanying documents' capacity to help readers understand the factors that led to certain results. In this light, readability acquires a fundamental importance: It does not matter how accurate the financial statement is, as without a good narrative section, it does not fulfill accountability requirements. Therefore, it is possible to state that the government's requirement for more accountability with the recent reform necessarily involves a narrative section in the Notes to a financial statement that is clear, understandable, and appropriate.

This paper carried out an exploratory investigation of the first university financial statements created according to the accrual rules. The study highlighted that the readability of Notes to financial statements was just sufficient after the initial transition, and it suggested that the government should introduce new and different mechanisms to enhance the readability of the narrative section of the balance sheet. In fact, the average value of both indexes was around 0.6 (the readability is considered good for values greater than 0.7 ). This work also highlighted the lack of influence of size or the geographical variables on the readability of the disclosure.

Given these results, it is possible to make preliminary conclusions. The low value of the readability index signifies that the accountants have found it difficult to provide a clear view of the university management. This difficulty has created a reduction in the transparency level and a consequent reduction of the degree of accountability. In addition, it is possible to state that providing disclosure that is difficult to read is like creating something un-useless. In this way, it is also possible to state that unintelligible disclosure implies a reduction in the level of accountability.

This research has several implications for practitioners, regulators and final users. First, it highlights the difficulty of practitioners, especially university accountants, when it comes to drafting an understandable disclosure that would be compliant with the new regulatory expectations. Therefore, it seems appropriate to reconsider the working methodology that leads to the creation of the Notes to the financial statements in universities. Second, this paper provides an important implication for regulators. Indeed, what should be noted is that there is a strong need for the introduction of a set of rules and recommendations that should drive accountants toward the transition to accrual accounting. These rules should include a panel of ad hoc principles to make the balance sheet more accountable. Finally, this research aims to provide implications for financial statement users (such as the Department of Education and Skills) concerning the correct interpretation of information that is considered difficult to read and understand, especially in such a delicate phase.

The research had some limitations. First, it did not identify the existence of a causal relationship between the 
readability index and the investigated variables; rather, it merely explained the average difference between the groups obtained from the sample. In addition, since it was limited to the first assessment, the study did not capture any critical issues related to the transition that could be better explained in future research.

\section{References}

Almquist, R., Grossi, G., van Helden, G. J., \& Reichard, C. (2013). Public sector governance and accountability. Critical Perspectives on Accounting, 24(7-8), 479-487. https://doi.org/10.1016/j.cpa.2012.11.005

Anessi Pessina, E., \& Steccolini, I. (2007). Sistemi contabili pubblici a un bivio: Come cogliere un'occasione di rinnovamento. Economia \& Management, (6), 60-61.

Anselmi, L., Pavan, A., \& Reginato, E. (2012). Cassa, competenza finanziaria e competenza economica: la scelta delle basi contabili in un sistema armonizzato di contabilità pubblica. Azienda Pubblica, 1, 53-67.

Barnett, A., \& Leoffler, K. (1979). Readability of accounting and auditing messages. Journal of Business Communication, 16(3), 49-59. https://doi.org/10.1177/002194367901600305

Beattie, V., McInnes, B., \& Fearnley, S. (2004, September). A methodology for analysing and evaluating narratives in annual reports: a comprehensive descriptive profile and metrics for disclosure quality attributes. In Accounting forum (Vol. 28, No. 3, pp. 205-236). Elsevier. https://doi.org/10.1016/j.accfor.2004.07.001

Biddle, G. C., Hilary, G., \& Verdi, R. S. (2009). How does financial reporting quality relate to investment efficiency? Journal of accounting and economics, 48(2), 112-131. https://doi.org/10.1016/j.jacceco.2009.09.001

Bloomfield, R. J. (2002). The "incomplete revelation hypothesis" and financial reporting. Accounting Horizons, 16(3), 233-243. https://doi.org/10.2308/acch.2002.16.3.233

Borgonovi, E. (2001). Principi e sistemi aziendali per le amministrazioni pubbliche. Egea.

Bovens, M. (2010). Two Concepts of Accountability: Accountability as a Virtue and as a Mechanism. West European Politics, 33(5), 946-967. https://doi.org/10.1080/01402382.2010.486119

Bozanic, Z., \& Thevenot, M. (2015). Qualitative Disclosure and Changes in Sell - Side Financial Analysts' Information Environment. Contemporary Accounting Research, 32(4), 1595-1616. https://doi.org/10.1111/1911-3846.12123

Caldarelli, A., Allini, A., Spanò, R. (2014). Il bilancio sociale nelle Università tra compliance formale e disclosure sostanziale. Un? analisi empirica nel contesto italiano. AZIENDA PUBBLICA, 3(3), 10-22.

Caperchione, E. (2000). Trends and open issues in governmental accounting systems: some elements of comparison. In Comparative Issues in Local Government Accounting (pp. 69-85). Springer US. https://doi.org/10.1007/978-1-4615-4581-1_5

Catturi, G., Grossi, G., \& Riccaboni, A. (2004). Evoluzione storica e prospettive della contabilità negli Atenei italiani. Annali di storia delle Università italiane, 8, 1-14.

Chavkin, L. (1997). Readability and reading ease revisited: State-adopted science textbooks. The Clearing House: A Journal of Educational Strategies, Issues and Ideas, 70(3), 151-154. https://doi.org/10.1080/00098655.1997.10543915

Cinquini, L. (2002). Il bilancio consuntivo delle università: verso una nuova informativa economico-finanziaria. Giappichelli.

Courtis, J. K. (1995). Readability of annual reports: Western versus Asian evidence. Accounting, Auditing \& Accountability Journal, 8(2), 4-17. https://doi.org/10.1108/09513579510086795

Dale, E., \& Chall, J. S. (1948). A formula for predicting readability: Instructions. Educational research bulletin, 37-54.

D'Alessio, L. (2012). Logiche e criteri di armonizzazione nelle recenti normative di riforma della contabilità pubblica. Azienda pubblica, 1, 23-40.

Flory, S. M., Phillips, T. J., \& Tassin, M. F. (1992). Measuring readability: A comparison of accounting textbooks. Journal of Accounting Education, 10(1), 151-161. https://doi.org/10.1016/0748-5751(92)90022-W

Franchina, V., \& Vacca, R. (1986). Adaptation of Flesh readability index on a bilingual text written by the same author both in Italian and English languages. Linguaggi, 3, 47-49.

Gunning, R. (1969). The fog index after twenty years. Journal of Business Communication, 6(2), 3-13. 
https://doi.org/10.1177/002194366900600202

Guthrie, J., \& Parker, L. D. (1990). Corporate social disclosure practice: a comparative international analysis. Advances in public interest accounting, 3, 159-175.

Haniffa, R. M., \& Cooke, T. E. (2002). Culture, corporate governance and disclosure in Malaysian corporations. Abacus, 38(3), 317-349. https://doi.org/10.1111/1467-6281.00112

Healy, P. (1977). Can you understand the footnotes to financial statements. Accountants Journal, 56, 219-222.

Hood, C. (1995). The "New Public Management" in the 1980s: variations on a theme. Accounting, organizations and society, 20(2-3), 93-109. https://doi.org/10.1016/0361-3682(93)E0001-W

Klare, G. R. (1974). Assessing readability. Reading research quarterly, 62-102. https://doi.org/10.2307/747086

Lapsley, I., \& Miller, P. (2004). Foreword: Transforming Universities: The Uncertain, Erratic Path. Financial Accountability \& Management, 20(2), 103-106. https://doi.org/10.1111/j.1468-0408.2004.00188.x

Lapsley, I., Mussari, R., \& Paulsson, G. (2009). On the adoption of accrual accounting in the public sector: a self-evident and problematic reform. https://doi.org/10.1080/09638180903334960

Lebar, M. A. (1982). A general semantics analysis of selected sections of the 10-k, the annual report to shareholders, and the financial press release. Accounting Review, 176-189.

Lehavy, R., Li, F., \& Merkley, K. (2011). The effect of annual report readability on analyst following and the properties of their earnings forecasts. The Accounting Review, 86(3), 1087-1115. https://doi.org/10.2308/accr.00000043

Li, F. (2008). Annual report readability, current earnings, and earnings persistence. Journal of Accounting and economics, 45(2), 221-247. https://doi.org/10.1016/j.jacceco.2008.02.003

Loughran, T., \& McDonald, B. (2014). Measuring readability in financial disclosures. The Journal of Finance, 69(4), 1643-1671. https://doi.org/10.1111/jofi.12162

Lucisano, P. (1988). Gulpease: una formula per la predizione della leggibilita di testi in lingua italiana. Scuola e città, 110-124.

Mc Laughlin, G. H. (1969). SMOG grading-a new readability formula. Journal of reading, 12(8), 639-646.

Monfardini, P. (2010). Accountability in the new public sector: a comparative case study. International Journal of Public Sector Management, 23(7), 632-646. https://doi.org/10.1108/09513551011078897

Mussari, R. (2012). Brevi considerazioni sui mutamenti in atto nei sistemi di contabilità pubblica. Azienda pubblica, 25(1), 11-21.

Mussari, R., \& Sostero, U. (2014). Il processo di cambiamento del sistema contabile nelle università: aspettative, difficoltà e contraddizioni. Azienda Pubblica, 2, 121-143.

Olson, O., Guthrie, J., \& Humphrey, C. (1998). Global warning: Debating international developments in new public financial management. Cappelen Akademisk Folag.

Paolini A., \& Soverchia M. (2015), La programmazione delle università italiane si rinnova: riflessioni e primi riscontri empirici. Azienda Pubblica, 3-2015, 287-308. https://doi.org/10.1007/978-3-319-07905-9_3

Paolini, A., \& Soverchia, M. (2013). Le università statali italiane verso la contabilità economico-patrimoniale ed il controllo di gestione. Management Control. https://doi.org/10.1111/j.1468-0408.1992.tb00211.x

Paolini, A., \& Soverchia, M. (2014). Public Italian Universities Towards Accrual Accounting and Management Control. In Information Systems, Management, Organization and Control (pp. 29-45). Springer International Publishing. https://doi.org/10.1177/109821409801900308

Patton, J. M. (1992). Accountability and governmental financial reporting. Financial Accountability \& Management, 8(3), 165-180. https://doi.org/10.1111/j.1467-1770.1994.tb01115.x

Perrin, B. (1998). Effective use and misuse of performance measurement. The American Journal of Evaluation, 19(3), 367-379.

Pica, T. (1994). Research on Negotiation: What Does It Reveal About Second - Language Learning Conditions, Processes, and Outcomes?. Language learning, 44(3), 493-527.

Riccaboni, A., \& Galgani, C. (2010). Board e membri esterni nella governance interna delle università italiane: nuovi trend e questioni emergenti. Azienda pubblica, 3. 
Ricci P., Parnoffi M. (2013), Il sistema universitario italiano alla luce delle recenti riforme. Questioni di governance, di finanziamento e di performance nella prospettiva della rendicontazione sociale, in Cassone A., Sacconi L. (a cura di), Autonomia e responsabilità dell'università. Governance e accountability, Milano: Giuffré, pp. 113-147.

Roberts, J., \& Scapens, R. (1985). Accounting systems and systems of accountability—understanding accounting practices in their organisational contexts. Accounting, Organizations and Society, 10(4), 443-456. https://doi.org/10.1016/0361-3682(85)90005-4

Schrand, C. M., \& Walther, B. R. (2000). Strategic benchmarks in earnings announcements: The selective disclosure of prior-period earnings components. The Accounting Review, 75(2), 151-177. https://doi.org/10.2308/accr.2000.75.2.151

Seah, S. S., \& Tarca, A. (2006). The impact of regulatory framework on management commentary reports. http//ssm. com/abstract, 962628.

Smith, J. E., \& Smith, N. P. (1971). Readability: A measure of the performance of the communication function of financial reporting. The Accounting Review, 46(3), 552-561.

Smith, M., \& Taffler, R. (1992). Readability and understandability: Different measures of the textual complexity of accounting narrative. Accounting, Auditing \& Accountability Journal, 5(4). https://doi.org/10.1108/09513579210019549

Steccolini, I. (2004). Accountability e sistemi informativi negli enti locali: dal rendiconto al bilancio sociale. G. Giappichelli.

Ter Bogt, H. J., \& Scapens, R. W. (2012). Performance management in universities: Effects of the transition to more quantitative measurement systems. European Accounting Review, 21(3), 451-497. https://doi.org/10.1080/09638180.2012.668323

Wallace, R. O., Naser, K., \& Mora, A. (1994). The relationship between the comprehensiveness of corporate annual reports and firm characteristics in Spain. Accounting and business research, 25(97), 41-53. https://doi.org/10.1080/00014788.1994.9729927

Weber, R. P. (1990). Basic content analysis (No. 49). Sage. https://doi.org/10.4135/9781412983488

\section{Copyrights}

Copyright for this article is retained by the author(s), with first publication rights granted to the journal.

This is an open-access article distributed under the terms and conditions of the Creative Commons Attribution license (http://creativecommons.org/licenses/by/4.0/). 